\title{
BACTERIOPHAGES OF LACTOCOCCUS LACTIS SSP. AND STREPTOCOCCUS THERMOPHILUS ISOLATED IN DAIRY PROCESSING PLANTS OF UKRAINE
}

\author{
O.V. Naumenko ${ }^{1}$, I.Y. Skrypkina ${ }^{2}$, S.I. Voychuk ${ }^{3}$, \\ N.A. Korol', F.I. Tovkach ${ }^{3}$, N.F. Kigel ${ }^{1}$ \\ ${ }^{I}$ Institute of Food Resources, National Academy of Agrarian Sciences of Ukraine, \\ 4 a E. Sverstiuk Str., Kyiv, 02002, Ukraine \\ ${ }^{2}$ Institute of Molecular Biology and Genetics, NAS of Ukraine, \\ 150 Acad. Zabolotny Str., Kyiv, 03143, Ukraine \\ ${ }^{3}$ Zabolotnyy Institute of Microbiology and Virology, NAS of Ukraine, \\ 154 Acad. Zabolotny Str., Kyiv, 03143, Ukraine \\ e-mail:ovnaumenko1@gmail.com
}

\begin{abstract}
Aims. Identification of Lactococcus lactis ssp. and Streptococcus thermophilus virulent bacteriophages isolated in dairy processing plants of Ukraine. Methods. The morphology of the viral particles was studied by transmission electron microscopy. Identification of structural proteins of phage was carried out by SDS-PAGE. The taxonomic position of phages was determined by multiplex PCR. Results. We presented results of the study of biological properties of 21 lactic acid bacteria phages isolated in dairy processing plants of Ukraine during 2007-2017. It was shown that phages had long, noncontractile tails, and therefore were classified to Caudovirales order, Siphoviridae family. Phages of L. lactis ssp. differed by head shape: phages with isometric heads of B1 morphotype and phages with prolate heads of B2 morphotype were detected. All analyzed S. thermophilus phages displayed specific morphology for B1 morphotype. Some of them had atypical shorter tails of 133-137 nm in length, with basal plates without globular appendages. Lytic activity spectrum of various phages was investigated and it was defined an absence of correlations between the indices of phages lytic activity and viral particles morphology. Phages of L. lactis ssp. were very heterogeneous on the basis of protein composition and formed three groups. Thus, c2 phages species differed by the fact that contained major proteins with greater molecular weights - 30, 55 and $72 \mathrm{kDa}$. Phages of S. thermophilus contained two or three major proteins with the molecular weights of 33 and $27 \mathrm{kDa} ; 42,26$, and $15 \mathrm{kDa}$, respectively. Conclusions. Bacteriophages of L. lactis ssp. according to their morphology, protein profile and PCR results were identified to species: 1) $38.1 \%$ of phages belong to species 936; 2) to the species P335-9.5\%; 3) to the species c $2-19.0 \%$. Phages $S$. thermophilus were identified to three groups: 1) the group of cos-type amounted to $14.3 \%$ of the total; 2) the group of pac-type - $9.5 \%$ and 3) 987 group - $9.5 \%$ of phages.
\end{abstract}

Keywords: Bacteriophages, Lactococcus lactis, Streptococcus thermophilus, Electron microscopy, Morphotype, Multiplex PCR, Protein profile.

Sensitivity of starter cultures to phage infections creates a number of complications during the production of various dairy products and cheeses and consequently leads to significant economic loss. Therefore, development of effective strategies for prevention and control of phage attacks is mandatory in dairy products manufacturing. In order to eliminate the negative effects of bacteriophages on lactic acid bacteria, precise characterization and classification of milk phages are required, as well as knowledge of the most 
efficient ways of phage detection and identification, understanding of their biological properties and the process of infection [1].

It was determined that genomes of all isolated lactic acid bacteria phages contain double-stranded DNA enclosed by a capsid, which is connected to a noncontractile tail, that is a characteristic feature for viruses of Caudovirales order. Bacteriophage taxonomy defines three families within this order: Myoviridae, Podoviridae and Siphoviridae. Most lactococcal phages have a long noncontractile tail (Siphoviridae family) and a small isometric capsid (morphotype B1) or a prolate capsid (morphotype B2). Several phages with short tails have also been isolated (Podoviridae family, morphotypes C2 and C3) [2].

According to electron microscopy studies and DNA - DNA hybridization results, Lactococcus lactis phages have been classified into 12 species. Phages of 936, P335 and c2 species are the most common and, accordingly, the ones that cause the greatest number of fermentation processes violations [3].

The number of cases of fermentation failure caused by phages active against Streptococcus thermophilus strains, the main components of starters for yoghurts, other dairy drinks and many rennet cheeses, has recently increased. According to the transmission electron microscopy data, phages of Streptococcus thermophilus belong to Siphoviridae family, morphotype B1: they posess small isometric heads and long noncontractile tails (there are also phages with short tails) [4].

It was observed the correlation between the $S$. thermophilus phage DNA packaging mechanism, so-called pac-and cos-types, and the number of major structural proteins visualized by SDS-PAGE [5].

Widescale studies of lactophages are necessary to elucidate and explain the phage-host interactions. These issues are particularly urgent in Ukraine, since such studies have not been carried out earlier, despite the high risk of phage contamination during processing of raw products, in particular, in fermented dairy and cheese manufacturing. Systematic research aimed at identification of bacteriophages circulating in Ukrainian dairy industry, their isolation, study and creation of systematic phage collections have not been carried out and are urgently needed.

The purpose of this work is to study biological properties of the industrial isolates of bacteriophages active against lactic acid bacteria.

Materials and methods. Bacterial strains, cultivation conditions. Pure cultures of lactic acid bacteria belonging to species L. lactis ssp. lactis, L. lactis ssp. cremoris, L. lactis ssp. lactis biovar diacetylactis, $S$. thermophilus from the culture collection of the Institute of Food Resources (Kyiv) were grown at $30^{\circ} \mathrm{C}$ (L. lactis) and $41^{\circ} \mathrm{C}(S$. thermophilus) in $10 \%$ sterile skimmed milk or M17 broth (Oxoid, Hampshire, United Kingdom) containing 0.5\% glucose (GM17; Sigma-Aldrich, St. Louis, MO, USA) for L. lactis or $0.5 \%$ lactose (LM17; Sigma-Aldrich) for S. thermophilus, renewing them every 20-25 days. They were stored at $4{ }^{\circ} \mathrm{C} .1 \%$ of inoculum of $17-20 \mathrm{~h}$ culture was added into a tube with $9.0 \mathrm{ml}$ of GM17 or LM17 broth and cultivated at the optimal temperature for $17-20 \mathrm{~h}$. Then $1 \%$ of this inoculum was added into a tube with $9.0 \mathrm{ml}$ of GM17 or LM17 broth and cultivated at optimal temperature until reaching the exponential phase of growth $\left(\mathrm{OD}_{600}=0.6-0.7\right)$. 
Bacteriophage extraction. Phage extraction and titration were carried out on solid nutrient medium GM17 or LM17, using "double" agar technique with $\mathrm{CaCl}_{2}$ (Oxoid, $10 \mathrm{mmol} \mathrm{l}^{-1}$ ) and glycine (Oxoid, $100 \mathrm{mmol} \mathrm{l}^{-1}$ ) [6]. Plaque test was performed on Petri dishes containing mild 1.5\% w/v agar (Merck, Darmstadt, Germany, $20 \mathrm{ml}$ per dish), freshly prepared layer of lower agar and $3 \mathrm{ml}$ of top agar $\left(0.65 \% \mathrm{w} / \mathrm{v}\right.$ agar), that contained the inoculum of $5.0 \times 10^{7}$ CFU ml ${ }^{-1}$ culture in log-phase and $1 \mathrm{ml}$ of dilution of prepared sample filtrate (0.45 $\mu$ m-pore-size filters, Sartorius, Germany). To detect bacteriophages, specially selected phage-susceptible test cultures were used: L. lactis ssp. lactis $\mathrm{L}_{1} \mathrm{~L}_{3:} 63 \mathrm{c}$; L. lactis ssp. cremoris $\mathrm{C} 3$, L. lactis ssp. lactis biovar diacetilactis 4di; S. thermophilus 66/12; 27/1 from the collection of the Biotechnology Department of the Institute of Food Resources. The dishes were incubated at the optimal temperature for 24-36 h. Samples were taken from morphologically identical negative colonies of each phage isolate and was followed by the purification procedure including 5-7 consecutive cycles ( $1^{\text {st }}$ cycle: cocultivation of phages with test cultures in GM17 or LM17 broth untill visual lysis occurs and further sedimentation by centrifugation ( $15000 \mathrm{~g}$ for $10 \mathrm{~min})$. The diameters of plaques formed by the purified phages were measured using a caliper and represent the average of 10 random plaques chosen over three independent experiments.

Sensitivity of cultures to phages. The phage hosts were determined using a plaque test, by placing phages on a Petri dish with GM17 or LM17 $(1.5 \% \mathrm{w} / \mathrm{v}$ agar) with $\mathrm{CaCl}_{2}\left(10 \mathrm{mmol} \mathrm{l}^{-1}\right)$, glycine $\left(100 \mathrm{mmol} \mathrm{l}^{-1}\right)$ and the studied culture in log-phase of growth. Bacteriophages with the titre of $10^{7} \mathrm{PFU} \mathrm{ml}^{-1}, 0.02 \mathrm{ml}$ volume were used for tests. Dishes were incubated at the optimal temperature for 24-36 h. The strains which bacterial lawns demonstrated lysis zones after phage application were considered phagesensitive.

Phage concentration. The high titer bacteriophage lysates were prepared by consecutive infections of the host strain with the bacteriophage at an MOI (multiplicity of infection) of 0.1 to 1.0. After infection the culture was grown at optimal temperature in GM17 or LM17 supplemented with $\mathrm{CaCl}_{2}\left(10 \mathrm{mmol} \mathrm{l}^{-1}\right)$, glycine $\left(100 \mathrm{mmol} \mathrm{l}^{-1}\right)$ until completed lysis. The lysates were centrifuged for $15000 \mathrm{~g}$ for $10 \mathrm{~min}$ at temperature of $4^{\circ} \mathrm{C}$ for cells precipitation and the supernatant was filtered $(0.45 \mu \mathrm{m}$-pore-size filters).

Transmission electron microscopy. For adsorption of phage particles with the titre not less than $10^{9} \mathrm{PFU} \mathrm{ml^{-1 }}$ to formvar surface a copper mesh with a formvar substrate film was placed on a drop of phage preparation and held for $1 \mathrm{~h}$ at room temperature. Non-adhered phage particles were washed in deionized $\mathrm{H}_{2} \mathrm{O}$ for $10 \mathrm{~min}$ and immediately treated with uranyl acetate solution $(2 \% \mathrm{w} / \mathrm{v}, \mathrm{pH} 4.5)$ for $40 \mathrm{~s}$ at room temperature [7]. Microphotographs of phage particles were obtained using a transmission electron microscope JEM-1400 (Jeol, Japan) at $80 \mathrm{kV}$ voltage and instrumental magnification of x50.000100.000 .

Amplification of phage DNA by multiplex PCR. To define specific genetic types of phages, PCR was performed on the DNA isolated from phage lysates. Bacteriophage DNA was isolated from lysate obtained in high titres, according to Binetti et al. [8]. As reference, the conserervative genes of the three basic genetic types of lactic acid phages c2, 712 (936-species) and P335 were used. Primer sequences used for multiplex PCR analysis, with PCR prod- 
uct size and primer annealing temperature are the following: 936 forward, 5'-TCAATGGAAGACCAAGCGGA-3' and reverse, 5'-GTAGGAGACCAACCCAAGCC-3' $\left(58^{\circ} \mathrm{C}, 179 \mathrm{bp}\right)$; c2 , 5'-CAGGTGTAAAAGTTCGAGAACT-3' and 5'-CAGATAATGCACCTGAATCA-3' (58 ${ }^{\circ} \mathrm{C}, 474$ bp); P335, 5'-GAAGCTAGGCGAATCAGTAA-3' and 5'-GATTGCCATTTGCGCTCTGA-3' $\left(58^{\circ} \mathrm{C}, 682 \mathrm{bp}\right)$ [9]. To identify the subtypes of phage S. thermophilus, multiplex PCR was used as suggested by Quiberoni et al. [10] and McDonnell et al. [11] using the following primers: $\cos$, 5'-GGTTCACGTGTTTATGAAAAATGG-3' and 5'-AGCAGAATCAGCAAGCAAGCTGTT-3' (53 ${ }^{\circ} \mathrm{C}$, 170 bp); pac 5'-GAAGCTATGCGTATGCAAGT-3' and 5'-TTAGGGATAAGAGTCAAGTG-3' (53ㄷ, 427 bp); 987 5'-CTAAGCGTTTGCCACTGTCAG-3' and 5'-GCTGCCGCTTGTTTGAAAAC-3' (55 ${ }^{\circ} \mathrm{C}, 707$ bp); 5093, 5'-CTGGCTCTTGGTGGTCTTGC-3' and 5'-GCGGCAACCATCTT AGACCAG-3' $\left(55^{\circ} \mathrm{C}, 983 \mathrm{bp}\right)$. PCR was performed on the phage samples with a titre of at least $10^{10} \mathrm{PFU} \mathrm{ml} \mathrm{m}^{-1} .50 \mathrm{ng}$ of the isolated DNA was used as template for PCR. DNA was amplified in $40 \mu \mathrm{l}$ PCRs using each sequence-specific primer at $0.4 \mu \mathrm{mol} \mathrm{l}^{-1}, 0.2 \mathrm{mmol} \mathrm{l}^{-1} \mathrm{dNTPs}, 1.5 \mathrm{U}$ Dream Taq DNA polymerase and the manufacturer's buffer with $2.0 \mathrm{mmol} \mathrm{l}^{-1} \mathrm{MgCl}_{2}$ (Thermo Fisher Scientific, Inc., Vilnius, Lithuania). PCR amplifications consisted of an initial denaturing step at $95^{\circ} \mathrm{C}$ for $4 \mathrm{~min}$, followed by 40 cycles of $95^{\circ} \mathrm{C}$ for $40 \mathrm{~s}$, appropriate annealing temperature for $40 \mathrm{~s}$, and $72^{\circ} \mathrm{C}$ for $1 \mathrm{~min}$, with the final extension step at $72^{\circ} \mathrm{C}$ for $7 \mathrm{~min}$. Each sample was assayed in triplicate, and each run included water blanks to eliminate the risk of contamination. PCR was performed in Applied Biosystems 2720® thermal cycler (Applied Biosystems; Thermo Fisher Scientific, Inc.). PCR products were analyzed by ethidium bromide stained $1.0 \%$ TAE-agarose gels electrophoresis in TAE buffer $\left(40 \mathrm{mmol} \mathrm{l}^{-1}\right.$ Tris-acetate, $1 \mathrm{mmol}^{-1}$ EDTA) using Wide Mini-Sub Cell GT Cell and PowerPac Basic Power Supply, 100-120/220-240 V (Bio-Rad, USA). The ladder is supplied with 6XDNA Loading Dye. The product size was determined using "GeneRulerTM DNA Ladder Mix" (Fisher Scientific, Inc., Vilnius, Lithuania). Detection of the gel images was carried out at ChemiDoc ${ }^{\mathrm{TM}} \mathrm{XRS}+\mathrm{System}$ (BioRad Laboratories, Inc., Hercules, CA, USA).

Structural protein identification by SDS-PAGE. Protein gel electrophoresis in SDS-polyacrylamide gel (SDS-PAGE) was performed by the Laemmli method [12]. Precipitated phage particles in SM buffer with a titre of at least $10^{10} \mathrm{PFU} \mathrm{ml} \mathrm{m}^{-1}$ (approximately $50 \mu \mathrm{l}$ ) were boiled for $3 \mathrm{~min}$ for damage to phage DNA. Then the product was treated with $4 \mu \mathrm{g} \mathrm{ml}^{-1}$ DNase I (Thermo Scientific, Fermentas) at $37^{\circ} \mathrm{C}$ for $30 \mathrm{~min}$ and 5xSDS-PAGE loading buffer (250 mmol $\mathrm{1}^{-1}$ Tris $\mathrm{HCl}, \mathrm{pH} 6.8,10 \%(\mathrm{w} / \mathrm{v}) \mathrm{SDS}, 0.5 \%(\mathrm{w} / \mathrm{v})$ bromophenol blue, $\mathrm{pH} 6.8$, $50 \%(\mathrm{w} / \mathrm{v})$ glycerol, $0.5 \%(\mathrm{w} / \mathrm{v}) \mathrm{b}$-mercaptoethanol) was added and boiled for $10 \mathrm{~min}$. Proteins were separated using SDS-PAGE (15\%) using a system for vertical electrophoresis VE-10 (Helicon, Russia). Electrophoresis was performed in a buffer for electrophoresis (248 mmol $\mathrm{m}^{-1}$ Tris-HCl, $\mathrm{pH} 8.8,1.92$ mol $1^{-1}$ glycine, $20 \mathrm{mmol} \mathrm{l}^{-1}$ EDTA, 1\% (w/v) SDS) for $20 \mathrm{~mA}$ until the front of the dye reached the bottom of the gel. Proteins were stained with Coomassie brilliant blue R-250 (Sigma). Detection of the gel images was carried out at ChemiDoc ${ }^{\mathrm{TM}} \mathrm{XRS}+$ System and proteins size were determined with Image Lab software, version 4.2.1 (Bio-Rad), using the PageRuler Prestained Protein Ladder (Thermo Scientific, Lithuania) as the standard. 
Results. Phage monitoring, phages selection, host range. 675 whey samples were analyzed for the presence of bacteriophages. The samples were taken from dairy processing factories (20 units) from 15 different regions of Ukraine at various time points (collected in the period of 2007-2017). It was determined that about $60 \%$ of samples were contaminated with bacteriophages of lactobacteria of different taxa. From the objects of phage monitoring - the most contaminated phage-containing samples (with level II of phage contamination from $10^{2}$ to $10^{4} \mathrm{PFU} \mathrm{ml}{ }^{-1}$ and level III - from $10^{5}$ and more PFU ml ${ }^{-1}$ ), 382 phages active against L. lactis ssp. and $S$. thermophilus were isolated.

A systematized collection of lactic acid bacteria phages is the basis for genetic research and scientific and practical development of anti-phage measures. At the first stage of creation of such a collection, 21 phage isolates were based on their ability to effectively reproduce on selected homologous cultures of lactic acid bacteria and were accumulated at titres of $8.7 \times 10^{8}$ $2.8 \times 10^{10}$ PFU ml-1 (Table 1 ).

Bacteriophage morphology. It was shown that phages had long, noncontractile tails, and therefore were classified to Caudovirales order, Siphoviridae family. Phages differed by head shape: phages with isometric heads of B1 morphotype and phages with prolate heads of B2 morphotype were detected. The study of morphological and morphometric properties of viral particles from the collection of biotechnology department showed that phages can be divided into 5 groups (Table 2). It was found that the majority of the studies phages

Table 1

Basic properties of phages

\begin{tabular}{|c|c|c|c|c|}
\hline $\begin{array}{l}\text { Phage } \\
\text { name }\end{array}$ & $\begin{array}{c}\text { Test } \\
\text { culture }\end{array}$ & $\begin{array}{c}\text { Titre }^{\mathrm{a}}, \\
\text { PFU ml } \mathbf{~}^{-1}\end{array}$ & $\begin{array}{c}\text { Negative colonies } \\
\text { morphology }\end{array}$ & $\begin{array}{l}\text { Diameter } \\
\text { zone }^{\mathrm{b}}, \mathrm{mm}\end{array}$ \\
\hline$\Phi 9 / 1$ & L. lactis ssp. lactis $\Omega_{3}$ & $2.0 \times 10^{9}$ & even edge, without aureole & $1.0-2.0$ \\
\hline$\Phi 14$ & L. lactis ssp. ssp. cremoris C3 & $9.0 \times 10^{9}$ & even edge, without aureole & $1.0-3.0$ \\
\hline$\Phi 4 \mathrm{dl}$ & $\begin{array}{c}\text { L. lactis ssp. lactis biovar } \\
\text { diacetylactis } 4 \mathrm{dl}\end{array}$ & $1.8 \times 10^{10}$ & even edge, without aureole & $2.5-4.0$ \\
\hline$\Phi 11$ & L. lactis ssp. ssp. cremoris C3 & $1.9 \times 10^{10}$ & homogeneous sterile zones & $2.8-3.5$ \\
\hline$\Phi \mathrm{O}_{15}$ & L. lactis ssp. lactis $Л_{1}$ & $2.5 \times 10^{9}$ & even edge, without aureole & $1.5-2.8$ \\
\hline$\Phi 8 / 2$ & L. lactis ssp. ssp. cremoris C3 & $2.8 \times 10^{10}$ & even edge, without aureole & $2.0-2.5$ \\
\hline$\Phi \mathrm{O}_{14}$ & L. lactis ssp. lactis 63 & $7.2 \times 10^{9}$ & sterile inside, cloudy at the edges & $1.0-2.0$ \\
\hline$\Phi 8 \mathrm{~L}$ & L. lactis ssp. lactis 63 & $3.7 \times 10^{9}$ & sterile inside, cloudy at the edges & $1.0-2.5$ \\
\hline$\Phi 8 \mathrm{D}$ & L. lactis ssp. lactis 63 & $1.0 \times 10^{9}$ & sterile zones, small & $1.0-1.5$ \\
\hline$\Phi \operatorname{Pr} 3-8$ & L. lactis ssp. lactis 63 & $1.1 \times 10^{10}$ & even edge, without aureole & $2.5-3.0$ \\
\hline$\Phi \mathrm{F} / 2$ & L. lactis ssp. lactis $\Omega_{3}$ & $2.4 \times 10^{10}$ & even edge, aureole is large & $3.0-7.0$ \\
\hline$\Phi y / 4$ & L. lactis ssp. lactis $Л_{1}$ & $4.0 \times 10^{9}$ & sterile inside, cloudy at the edges & $1.0-2.5$ \\
\hline$\Phi y / 3$ & L. lactis ssp. lactis $Л_{3}$ & $1.1 \times 10^{10}$ & sterile inside, cloudy aureole & $2.5-3.0$ \\
\hline$\Phi \mathrm{c} / 1$ & L. lactis ssp. lactis $\Omega_{1}$ & $3.1 \times 10^{9}$ & sterile inside, cloudy at the edges & $1.0-2.5$ \\
\hline$\Phi 3 / K$ & S. thermophilus $66 / 12$ & $1.5 \times 10^{9}$ & sterile inside, cloudy at the edges & $1.5-2.0$ \\
\hline$\Phi S_{61}$ & S. thermophilus $66 / 12$ & $2.2 \times 10^{10}$ & homogeneous sterile zones & $1.5-2.0$ \\
\hline$\Phi \mathrm{S}_{1}$ & S. thermophilus $66 / 12$ & $2.5 \times 10^{9}$ & blurred edge, without aureole & $1.5-2.0$ \\
\hline$\Phi \mathrm{O}_{20}$ & S. thermophilus $66 / 12$ & $2.7 \times 10^{10}$ & homogeneous sterile zones & $1.8-2.0$ \\
\hline ФNdan & S. thermophilus $27 / 1$ & $8.7 \times 10^{8}$ & sterile zones, small, blurred edge & $1.0-1.5$ \\
\hline$\Phi 36_{8}$ & S. thermophilus $66 / 12$ & $1.5 \times 10^{9}$ & sterile zones, small & $1.0-1.5$ \\
\hline$\Phi S_{27-1}$ & S. thermophilus $27 / 1$ & $8.7 \times 10^{8}$ & sterile zones, small, blurred edge & $1.0-1.5$ \\
\hline
\end{tabular}


belonged to B1 morphotype. Phages of B1 morphotype formed 4 subgroups depending on their tail size. Virion sizes are provided in Table 2. Examples of electronograms of viruses representing each group are shown in Fig. 1.

Table 2

\section{Ultrastructures of phages}

\begin{tabular}{|l|c|c|c|c|c|}
\hline $\begin{array}{l}\text { No. } \\
\text { group }\end{array}$ & Morphotype & Head shape & $\begin{array}{c}\text { Diameter } \\
\text { head }^{\mathbf{a}}, \mathbf{n m}\end{array}$ & $\begin{array}{c}\text { Tail size } \\
\mathbf{n m}\end{array}$ & $\begin{array}{c}\text { Number of phages, } \\
\mathbf{\%}\end{array}$ \\
\hline 1 & B1 & isometric capsid & $39-51$ & $110-142$ & 14.3 \\
\hline 2 & B1 & isometric capsid & $40-55$ & $163-207$ & 33.3 \\
\hline 3 & B1 & isometric capsid & $43-54$ & $205-291$ & 23.8 \\
\hline 4 & B1 & isometric capsid & $44-46$ & $133-137$ & 9.5 \\
\hline 5 & B2 & prolate capsid & $\begin{array}{c}31-40 x \\
42-51\end{array}$ & $79-102$ & 19.0 \\
\hline
\end{tabular}

a, b, The values are the mean of ten determinations.

\begin{tabular}{|c|c|c|c|c|}
\hline $\begin{array}{c}\text { morphotype B1 } \\
\text { group I }\end{array}$ & $\begin{array}{c}\text { morphotype B1 } \\
\text { group II }\end{array}$ & $\begin{array}{c}\text { morphotype B1 } \\
\text { group III }\end{array}$ & $\begin{array}{c}\text { morphotype B1 } \\
\text { group IV }\end{array}$ & $\begin{array}{c}\text { morphotype B2 } \\
\text { group V }\end{array}$ \\
\hline ( & & & & \\
& & & & \\
\hline A & B & C & D & E \\
\hline
\end{tabular}

Fig. 1. Electron micrographs of phages:

(A) $\Phi$ Pr 3-8 (group I); (B) $\Phi 11$ (group II); (C) $\Phi O_{20}$ (group III); (D) $\Phi S_{27-1}$ (group IV);

(E) $\Phi y / 4$ (group V). Bar represents, $100 \mathrm{~nm}$.

Phages of $S$. thermophilus from our samples had the structure of viral particles corresponding to B1 morphotype. It should be noted that part of phages that are active against bacteria of $S$. thermophilus species were characterized by atypical small size of tail - 133-137 $\mathrm{nm}$. We have identified such phages in group B1/4 (Table 2, Fig. 1 (D).

All phages were divided into 4 groups depending on their spectrum of lytic activity. It is interesting that lytic groups I, II and IV were divided into two subgroups each correlating with phage morphotype, and finally phages were divided into 7 groups, taking into account two properties: specificity and morphological structure of viral particles (Table 3).

PCR test for the identification of phages. Based on the size of the PCR products obtained, it was found that phages $\Phi F / 2, \Phi y / 4$ and $\Phi \mathrm{c} / 1$ are representative of $\mathrm{c} 2$ phages species. The electrophoregram shows (Fig. 2, lane 1, 5 and 7, respectively), the DNA of these phages forms amplicons $474 \mathrm{bp}$, which, according to other studies [9] are typical for the above-mentioned bacterial viruses.

Based on the size of the obtained PCR fragments, with a molecular weight of $682 \mathrm{bp}$, the phages $\Phi 8 \mathrm{D}$ and $\Phi \operatorname{Pr} 3-8$ were identified as P335 species (Fig. 2, lane 4 and 6 respectively). Three phages $\left(\Phi 14, \Phi \mathrm{O}_{15}\right.$ Ta $\left.\Phi 4 \mathrm{dl}\right)$ gave a 179-bp PCR product, indicating that they belong to the 936 species of phages (Fig. 2, lane 2, 8 and 9, respectively). 


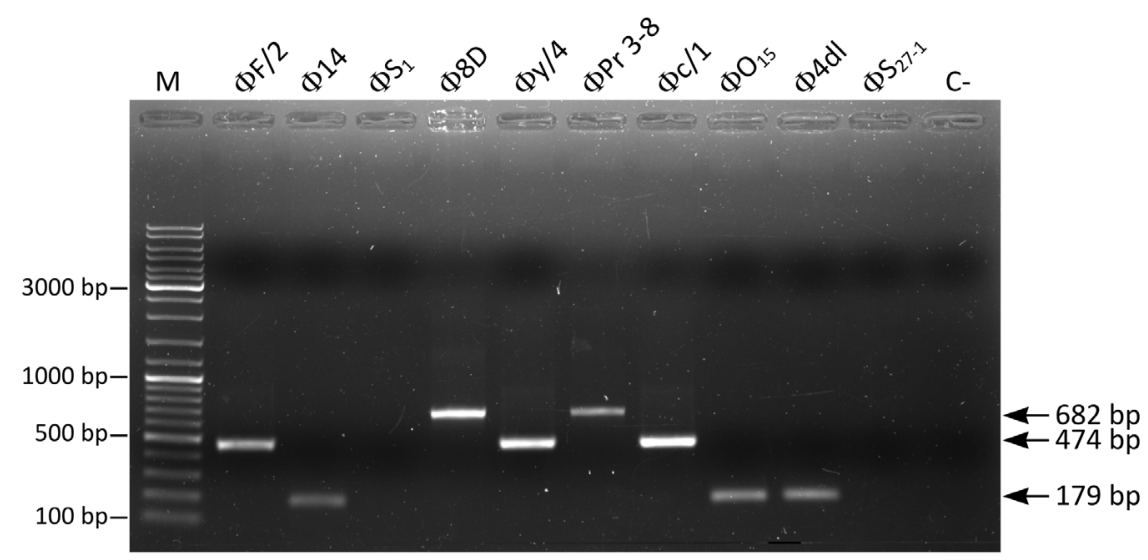

Fig. 2. Detection of $L$. lactis phages' DNA by multiplex PCR:

c2-type - 474 bp, P335 - 682 bp and 936 - 179 bp. $M$ - molecular weight marker GeneRuler"M DNA Ladder Mix ("Thermo Scientific", USA); C - negative control without DNA matrix

Table 3

Distribution of phages to lytic groups

\begin{tabular}{|l|c|c|c|}
\hline $\begin{array}{l}\text { Phages } \\
\text { subgroup }\end{array}$ & $\begin{array}{c}\text { Lytic } \\
\text { group }\end{array}$ & Lytic activity spectrum & Morphotype \\
\hline I & I & $\begin{array}{c}\text { L.lactis ssp lactis, L.lactis ssp cremoris, L.lactis ssp. } \\
\text { lactis biovar diacetylactis }\end{array}$ & B1 group 1 \\
\hline I I & I & $\begin{array}{c}\text { L.lactis ssp lactis, L.lactis ssp cremoris, L.lactis ssp. } \\
\text { lactis biovar diacetylactis }\end{array}$ & B2 \\
\hline III & II & $\begin{array}{c}\text { L.lactis ssp lactis, L.lactis ssp. lactis biovar } \\
\text { diacetylactis }\end{array}$ & B1 group 2 \\
\hline IV & II & $\begin{array}{c}\text { L.lactis ssp lactis, L.lactis ssp. lactis biovar } \\
\text { diacetylactis }\end{array}$ & B2 \\
\hline V & III & L.lactis ssp cremoris & B1 group 1 \\
\hline VI & IV & S.thermophilus & B1 group 3 \\
\hline VII & IV & S.thermophilus & B1 group 4 \\
\hline
\end{tabular}

Using a set of primers for multiplex PCR to cos-and pac-types of $S$. thermophilus, fragments of $170 \mathrm{bp}$ were identified which indicated the belonging of the phages $\Phi \mathrm{S}_{1}, \Phi \mathrm{O}_{20}$ and $\Phi$ Ndan to the cos-types of $S$. thermophilus viruses (Fig. 3, lane 1, 2 and 4, respectively), and fragments $427 \mathrm{bp}$ for the phages $\Phi \mathrm{S}_{61}$ and $\Phi 3 / \mathrm{K}$, which were identified as representatives of the pac-containing viruses (Fig. 3, lane 5 and 6 , respectively).

In addition, among the phages of $S$. thermophilus, representatives of the new groups 987 and 5093 were identified, which were described by McDonnell et al. $[11,13]$. However, among the tested phages, we found only representatives of the 987 group of $S$. thermophilus phages $\Phi 36_{8}$ and $\Phi S_{27-1}$, which corresponded to the PCR products of $707 \mathrm{bp}$ (Fig.4, lane 4 and 7, respectively). Our sample did not contain phages similar to members of 5093 group, whose morphology is different from cos- and pac-phages, globular spherical appendages are found on baseplates of their tails. Representatives of the 5093 group (amplicon 983 bp) were not detected (Fig. 4). 


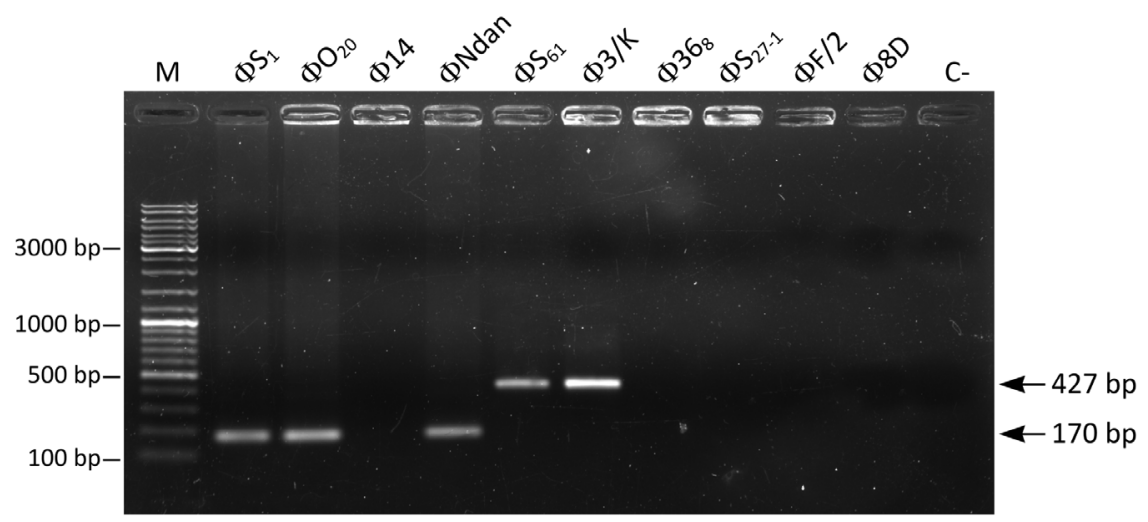

Figure 3 Detection of $S$. thermophilus phages' DNA by multiplex PCR: cos-type -170 bp and pac-type -427 bp. $M-$ molecular weight marker GeneRuler ${ }^{\mathrm{TM}}$ DNA Ladder Mix ("Thermo Scientific", USA); C - negative control without DNA matrix

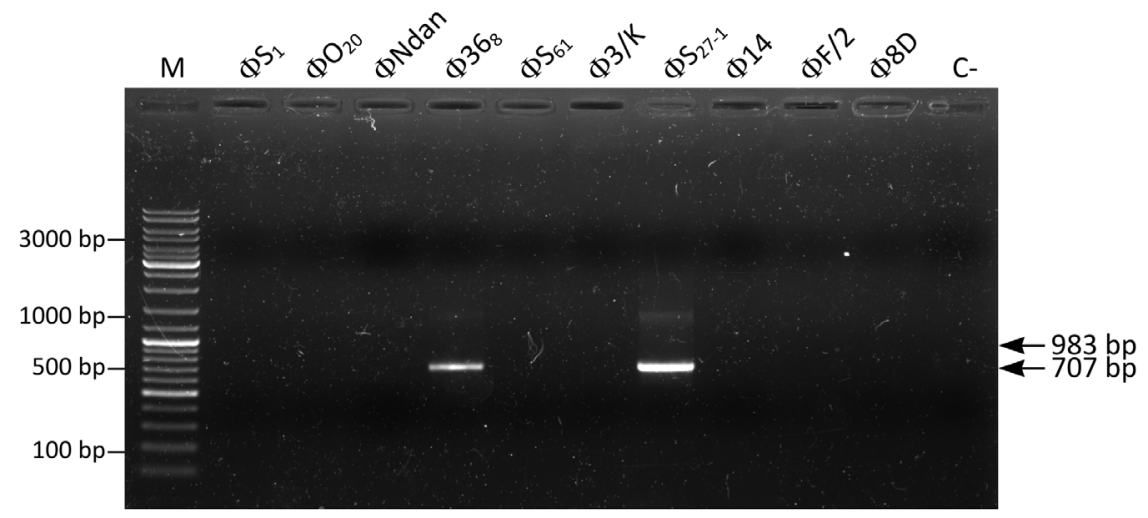

Fig. 4. Detection of $S$. thermophilus phages' DNA by multiplex PCR:

987-type -707 bp and 5093-type -983 bp (did not identify). M - molecular weight marker GeneRuler"M DNA Ladder Mix ("Thermo Scientific", USA); C - negative control without DNA matrix

Protein profile of phages. Phage particles derived from 3 different phages of $S$. thermophilus showed that they contain two major proteins with approximate molecular weights of 27 and $33 \mathrm{kDa}$ (for example, see Fig. 5, lane 6, phage $\left.\Phi \mathrm{O}_{20}\right)$. They used cos- mechanism of genome packaging, so they were classified as cos-type. Only two phages contained three major proteins with approximate molecular mass of 15, 26 and $42 \mathrm{kDa}$ (for example, see Fig. 5, lane 3, phage $\Phi \mathrm{S}_{61}$ ). They were classified into the phage group with pac-type of DNA packaging mechanism. Both profiles occasionally varied slightly $( \pm 1-4 \mathrm{kDa})$ from phage to phage.

In our sample L. lactis ssp. phages formed three groups according to their protein profiles. Thus, $\mathrm{c} 2$ phages species differed by the fact that contained major proteins with greater molecular weights - 30, 55 and $72 \mathrm{kDa}$ (for example, see Fig. 5, lane 5 and 7, phage $\Phi F / 2$; phage $\Phi y / 3)$. The phage $\Phi \mathrm{c} / 1$ (c2 phages species) contained major proteins with molecular weights of 40, 53 and $72 \mathrm{kDa}$ (Fig. 5, lane 9, phage $\Phi \mathrm{c} / 1$ ). Phages $\Phi 8 / 2, \Phi \mathrm{O}_{14}$ 
(936 phages species) contained major proteins with molecular weights of 29 and $53 \mathrm{kDa}$ (Fig. 5, lane 10 (phage $\Phi 8 / 2$ ) and lane 11 (phage $\Phi \mathrm{O}_{14}$ )). Phage $\Phi 36_{8}$ contained major proteins with molecular weights of 20,29 and $53 \mathrm{kDa}$ (Fig. 5, lane 1, phage $\Phi 36_{8}$ ).

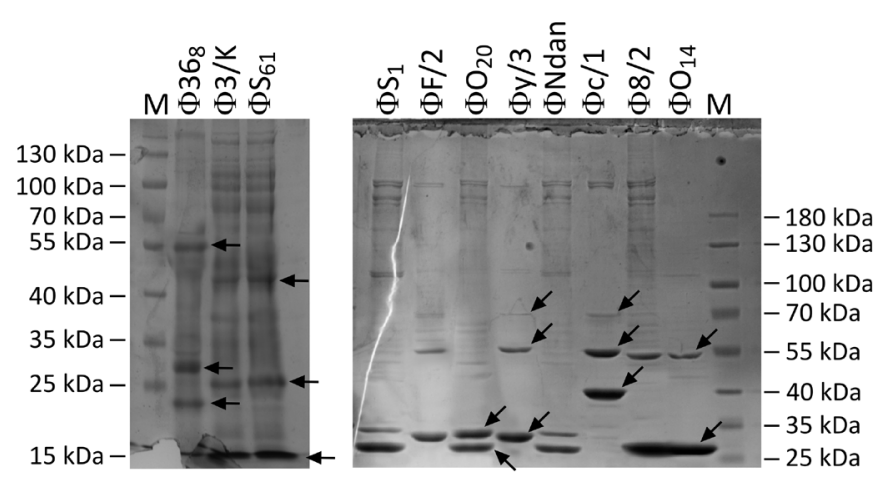

Fig. 5. Profile of $S$. thermophilus and $L$. lactis ssp. proteins of phages, separated using $15 \%$ SDS-PAGE. Black arrows indicate structural proteins of phages. $M$ - molecular weight marker PageRuler Prestained Protein Ladder (Thermo Scientific, Lithuania)

Discussion. In this article, we presented results of the study of basic biological properties of 21 lactic acid bacteria phages. These isolates are a representative part of a large phage collection of 382 phages isolated from samples which were obtained from dairy processing plants in various geographical locations in Ukraine and at various time points. Representative members of the phage collection used in this study were selected for identification analysis.

In accordance with the requirements of the International Committee on Taxonomy of Viruses, morphological and morphometric analysis of virus particles using the method of transmission electron microscopy was carried out for phage identification. It was defined that the majority of the examined phages belonged to B1 morphotype $-81 \%$. According to literature data phages of B1 morphotypes were mostly mentioned abroad, although descriptions of B2 morphotype phages can often be found. In Byelorussia there was determined the distribution of B2 morphotype, c2 species phages $-63.6 \%$ of the examined viruses [14], in Germany c2 species phages was also dominant [15].

Distribution of B1 morphotype phages in Ukraine coincides with the data of researches of many scientists. So, according to Szczepanska et al. [16] in Poland phages of 936 species (B1 morphotype) were identified more often in $69 \%$ of cases. Similar results were obtained by scientists from European countries, New Zealand, USA, Canada - lytic type of 936 species phages (B1 morphotype) predominated over c2 species phages (B2 morphotype) [7; 17$18]$.

All analyzed $S$. thermophilus phages displayed specific morphology for B1 morphotype, had isometric heads (43-54 $\mathrm{nm}$ in diameter) and noncontractile tails (205-291 nm in length). Also we observed phages that had isometric icosahedral heads of 44-46 nm in diameter, and noncontractile tails of a slightly shorter length, from 133 to $137 \mathrm{~nm}$, with basal plates on the tails without globular appendages. Such a morphology was described for S. thermophilus phages of 987-group by McDonnell et al. [13], Szymczak et al. [19]. 
Lytic activity spectrum of various phages was investigated and it was defined an absence of correlations between the indices of phages lytic activity and viral particles morphology. Binetti et al. showed, that phages S. thermophilus also are not possible to classify on the basis of traditional criteria only, since there is no correlation between morphology and host range of viruses [8].

As it is known, by number of major structural proteins, $S$. thermophilus phages are classified into two groups. Phages with cos-type of packing the genome contain two major proteins with a molecular weight of 26 and $32 \mathrm{kDa}$; phages with pac-type contain three major proteins with a molecular weight of $13 ; 25$ and $41 \mathrm{kDa}$ [5]. In our collection three phages were attributed to costype, and two phages used pac-type of DNA packing.

The phages L. lactis ssp. were very heterogeneous on the basis of protein composition. Presence of three major proteins with relatively high molecular weight in polypeptide profiles of $\mathrm{c} 2$ phages was shown also by Moineau et al. [7], Azaïez et al. [20], as well as a variable amount of minor proteins.

Conclusion. It was determined that phages of L. lactis ssp. according to morphological structure, polypeptide composition and PCR identification belonged to species: 1) species 936 (morphotype B1) - 38.1\% of the total; 2) species P335 (morphotype B1) - 9.5\% and 3) species c2 (morphotype B2) $19.0 \%$ of phages.

Based on the study of morphology, protein profile, PCR-analysis phages of S. thermophilus have been identified to three groups: 1) group of cos-type was $14.3 \%$ of the total; 2) group of pac-type was $9.5 \%$ and 3) 987 group $-9.5 \%$ of phages.

Thus, significant biodiversity of lactic acid bacteria phages is determined, as well as specific features of certain phages circulation in Ukrainian dairy processing plants. Reliable identification and proper determination of phages taxonomic position is very important for monitoring the distribution of phages during production, introduction of optimized phage monitoring methods, development of adequate rotational and selective phage-protective strategies.

\title{
БАКТЕ РIОФАГИ LACTOCOCCUS LACTIS SSP. I STREPTOCOCCUS THERMOPHILUS, ВИДІЛЕНІ НА МОЛОКОПЕРЕРОБНИХ ПІДПРИЄМСТВАХ УКРАЇНИ
}

\author{
О.В. Науменко ${ }^{1}$ І.Я. Скрипкіна ${ }^{2}$, С.І. Войчук, \\ Н.А. Король ${ }^{3}$, Ф.І. Товкач ${ }^{3}$, Н.Ф. Кігель ${ }^{1}$ \\ ${ }^{1}$ Інститут продовольчих ресурсів, Національна академія аграрних наук, \\ вул. С. Сверстюка, 4а, Київ, 02002, Україна \\ ${ }^{2}$ Інститут молекулярної біології і генетики НАН України, \\ вул. Акад. Заболотного, 150, Київ, 03143, Україна \\ ${ }^{3}$ Інститут мікробіології і вірусологї̈ ім. Д.К. Заболотного НАН Украӥни, \\ вул. Акад. Заболотного, 154, Київ, 03143, Україна
}

\section{Резюме}

Мета. Ідентифікація вірулентних бактеріофагів Lactococcus lactis ssp. i Streptococcus thermophilus, виділених на молокопереробних заводах України. Методи. Морфологію вірусних часток вивчали методом трансмісійної електронної мікроскопії. 
Ідентифікацію структурних білків фагів проводили за допомогою гель-електрофорезу в денатуруючих умовах. Таксономічне положення фагів визначали методом мультиплексної ПЛР. Результати. Наведено результати вивчення біологічних властивостей 21 фага молочнокислих бактерій, виділених на молокопереробних заводах України впродовж 2007-2017 pр. Було показано, що фаги мали довгі, нескоротливі хвости, і тому були класифіковані до порядку Caudovirales, сімейства Siphoviridae. Фаги L. lactis ssp. відрізнялись формою головки: виявлено фаги з ізометричними головками морфотипу В1 та фаги з витягнутими головками морфотипу В2. Всі проаналізовані фаги S. thermophilus мали морфологію, характерну для морфотипу В1. Деякі з них мали атипові короткі хвости довжиною 133-137 нм з базальними пластинами без глобулярних відростків. Вивчено спектр літичної активності різних фагів. Встановлено відсутність кореляції між показниками літичної активності та морфологією вірусних часток. Фаги L. lactis ssp. були дуже гетерогенними і утворювали три групи за білковим складом. Зокрема, фаги виду с2 відрізнялись тим, що містили мажорні білки з більшою молекулярною масою - 40, 53 і 72 кДа. Фаги S. thermophilus містили два або три мажорні білки з молекулярною масою 33 і 27 кДа; 42, 26 і 15 кДа відповідно. Висновки. Бактеріофаги L. lactis ssp. за їх морфологією, білковим профілем та результатами ПЛР ідентифіковані до видів: 1) до виду 936 віднесено $38.1 \%$ фагів; 2) до виду Р335 - 9.5 \%; 3) до виду с2 - $19.0 \%$. Фаги S. thermophilus були ідентифіковані до трьох груп: 1) група cos-типу становила $14.3 \%$ від загальної кількості фагів; 2) група рас-типу - 9.5 \% i 3) 987 група - $9.5 \%$ фагів.

Ключові слова: бактеріофаги, Lactococcus lactis, Streptococcus thermophilus, електронна мікроскопія, морфотип, мультиплексна ПЛР, білковий профіль.

\title{
БАКТЕРИОФАГИ LACTOCOCCUS LACTIS SSP. И STREPTOCOCCUS THERMOPHILUS, ВЫДЕЛЕННЫЕ НА МОЛОКОПЕРЕРАБАТЫВАЮЩИХ ПРЕДПРИЯТИЯХ УКРАИНЫ
}

\author{
О.В. Науменко, И.Я. Скрипкина ${ }^{2}$, С.И. Войчук', \\ Н.А. Король ${ }^{3}$ Ф.И. Товкач ${ }^{3}$, Н.Ф. Кигель ${ }^{1}$
}
${ }^{1}$ Институт продовольственных ресурсов, Национальная академия аграрных наук, ул. Е. Сверстюка, 4а, Киев, 02002, Украина
${ }^{2}$ Институт молекулярной биологии и генетики НАН Украинь,
ул. Акад. Заболотного, 150, Киев, 03143, Украина
${ }^{3}$ Институт микробиологии и вирусологии им. Д.К. Заболотного НАН Украинь,, ул. Акад. Заболотного, 154, Киев, 03143, Украина

\section{Резюме}

Цель. Идентификация вирулентных бактериофагов Lactococcus lactis ssp. и Streptococcus thermophilus, выделенных на молокоперерабатывающих заводах Украины. Методы. Морфологию вирусных частиц изучали методом трансмиссионной электронной микроскопии. Идентификацию структурных белков фагов проводили с помощью гель-электрофореза в денатурирующих условиях. Таксономическое положение фагов определяли методом мультиплексной ПЦР. Результаты. Приведены результаты изучения биологических свойств 21 фага молочнокислых бактерий, выделенных на молокоперерабатывающих заводах Украины в течение 2007-2017 гг. 
Показано, что фаги имели длинные, несокращающиеся хвосты и поэтому были классифицированы в порядок Caudovirales, семейство Siphoviridae. Фаги L. lactis ssp. отличались по форме головки: выявлены фаги с изометрическими головками морфотипа В1 и фаги с вытянутыми головками морфотипа В2. Все рассматриваемые фаги S. thermophilus имели морфологию, характерную для морфотипа В1. Некоторые из них имели атипичные короткие хвосты длиной 133-137 нм с базальными пластинами без глобулярных отростков. Изучен спектр литической активности различных фагов. Установлено отсутствие корреляции между показателями литической активности и морфологией вирусных частиц. Фаги L. lactis ssp. были очень гетерогенными и образовывали три группы по белковому составу. В частности, фаги вида с2 отличались тем, что имели мажорные белки с большей молекулярной массой -40 , 53 и 72 кДа. Фаги S. thermophilus содержали два или три мажорных белка с молекулярной массой 33 и 27 кДа; 42, 26 и 15 кДа соответственно. Выводы. Бактериофаги L. lactis ssp. в соответствии с их морфологией, белковым профилем и результатами ПЦР идентифицированы до видов: 1) к виду 936 отнесено $38.1 \%$ фагов; 2) к виду Р335 - $9.5 \%$; 3) к виду с2 - $19.0 \%$. Фаги $S$. thermophilus были идентифицированы в три группы: 1) группа $c o s$-типа составляла $14.3 \%$ от общего количества фагов; 2) группа рас-типа - $9.5 \%$ и 3) 987 группа - $9.5 \%$ фагов.

Ключевые слова: бактериофаги, Lactococcus lactis, Streptococcus thermophilus, электронная микроскопия, морфотип, мультиплексная ПЦР, белковый профиль.

1. Verreault D, Gendron L, Rousseau GM, et al. Detection of airborne lactococcal bacteriophages in cheese manufacturing plants. Appl Environ Microbiol. 2011; 77:491-497.

2. Moineau S, Lévesque $\mathrm{C}$ Control of bacteriophages in industrial fermentation. In Bacteriophages: Biology and Applications. ed. Kutter, E. and Sulakvelidze, A. Boca Raton, Fla: CRC Press; 2005. p. 286-296.

3. Brüssow H, Desiere F Comparative phage genomics and the evolution of Siphoviridae: insights from dairy phages. Mol Microbiol. 2001; 39:213-222.

4. Ackermann H-W 5500 Phages examined in the electron microscope. Arch Virol. 2007; 152:277-243.

5. Quiberoni A, Moineau S, Rousseau GM, Reinheimer J, Ackermann H-W Streptococcus thermophilus bacteriophages. Int Dairy J. 2010; 20:657-664.

6. Lillehaug D An improved plaque assay for poor plaque-producing temperate lactococcal bacteriophages. J Appl Microbiol. 1997; 83:85-90.

7. Moineau S, Fortier J, Ackermann H-W, Pandian S Characterization of lactococcal bacteriophages from Quebec cheese plants. Can J Microbiol. 1992; 38:875-882.

8. Binetti AG, del Rio B, Martin MC, Alvarez MA Detection and characterization of Streptococcus thermophilus phages based on the antireceptor gene sequence. Appl Environ Microbiol. 2005; 71:6096-6103.

9. Labrie S, Moineau S Multiplex PCR for detection and identification of lactococcal bacteriophages. Appl Environ Microbiol. 2000; 66:987-994.

10. Quiberoni A, Tremblay D, Ackermann H-W, Moineau S, Reinheimer JA Diversity of Streptococcus thermophilus phages in a large-production cheese factory in Argentina. J Dairy Sci. 2006; 89(10):3791-3799. 
11. McDonnell B, Mahony J, Hanemaaijer L, Neve H, Noben J-P, Lugli GA, et al. Global survey and genome exploration of bacteriophages infecting the lactic acid bacterium Streptococcus thermophilus. Front Microbiol. 2017;8: 1754/https://doi.org/10.3389/ fmicb.2017.01754.

12. Laemmli UK Cleavage of structural proteins during the assembly of the head of bacteriophage T4. Nature. 1970; 227: 680-685.

13. McDonnell B, Mahony J, Neve H, Hanemaaijer L, Noben J-P, Kouwen T, et al. Identification and analysis of a novel group of bacteriophages infecting the lactic acid bacterium Streptococcus thermophilus. Appl Environ Microbiol. 2016; 82(17):5153-5165.

14. Raiski A, Belyasova N Biodiversity of Lactococcus lactis bacteriophages in the Repablic of Belarus. Int J Food Microbiol. 2009; 130:1-5.

15. Josephsen J, Petersen A, Neve H, Nielsen EW Development of lytic Lactococcus lactis bacteriophages in a Cheddar cheese plant. Int J Food Microbiol. 1999; 50:163-171.

16. Szczepanska AK, Hejnowicz MS, Kolakowski P, Bardowski J Biodiversity of Lactococcus lactis bacteriophages in Polish dairy environment. ABP. 2007; 54:151-158.

17. Bissonnette F, Labrie S, Deveau H, Lamoureux M, Moineau S Characterization of mesophilic mixed starter cultures used for the manufacture of aged cheddar cheese. J Dairy Sci. 2000; 83:620-627.

18. Miklic A, Rogelj I Characterization of lactococcal bacteriophages isolated from Slovenian dairies. Int J Food Sci Technol. 2003; 38:305-311.

19. Szymczak P, Janzen T, Neves AR, Kot W, Hansen LH, Lametsch R, et al. Novel variants of Streptococcus thermophilus bacteriophages are indicative of genetic recombination among phages from different bacterial species. Appl Environ Microbiol. 2017; 83(5):2748-2764.

20. Azaïez SRC, Fliss I, Simard RE, Moineau S Monoclonalantibodies raised against native major capsid proteins of lactococcal c2-like bacteriophages. Appl Environ Microbiol. 1998; 64:4255-4259.

Отримана 20.09.2018 